\title{
AGRICULTURAL USE OF ANAEROBICALLY DIGESTED WETLAND BIOMASS
}

\author{
Robert Czubaszek, Agnieszka Wysocka-Czubaszek, Slawomir Roj-Rojewski, Piotr Banaszuk \\ Bialystok University of Technology, Poland \\ r.czubaszek@pb.edu.pl
}

\begin{abstract}
Along with the development of anaerobic digestion processes, digestate, a by-product of biogas production has emerged as a new organic soil amendment. One of the substrates in anaerobic digestion is biomass of plants mown in wetlands as a part of extensive conservation measures. However, this biomass can be used also as fodder in animal production. Feed value of wetland plants varies and the system of numerical values (Lwu) can be used to compare the nutritional values of individual plant species. The aim of the research was to evaluate suitability of studied wetland plants for energy production and further for fertilization and feeding purposes. The examined digestates were obtained in the laboratory experiment on the bio-methane potential of five plant species. The degree of transformation of fermented organic matter was determined based on the results of the earlier experiment concerning $\mathrm{CO}_{2}$ emissions from soils enriched with the studied digestates. Among tested plants, reed canary grass (R-C) with $L w u=7$ had the highest feed value, while one of the worst was for common reed $(\mathrm{C}-\mathrm{R})$ with $L w u=1$. This classification looks interesting, when we compare it with the results of the $\mathrm{CO}_{2}$ emissions and degree of mineralization of $\mathrm{OM}$ supplied to soils with individual plant digestates. Among the studied wetland plants, the highest emission and the largest amount of potentially mineralized carbon had reed canary grass, while the lowest emission and lowest amount of mineralized carbon in the case of common reed was observed. As a result, C-R turned out to be the plant that used for biogas production was enriching soil with the largest amount of carbon delivered with the material remaining after anaerobic digestion. At the same time, C-R is one of the worst fodder plants, while $\mathrm{R}-\mathrm{C}$ is the best one. Therefore, despite the fact that reed canary grass is characterized by high yield potential and belongs to plants with very good energy properties, it should be first of all used for animals feeding.
\end{abstract}

Keywords: wetland biomass, digestate, forage, soil organic carbon, plants utility value.

\section{Introduction}

In recent years, interest in wetland areas has increased. It is related to their importance in the field of ecosystem services as a water purifying element, the regulator of water circulation in the environment, places for recreation [1] as well as the supplier of significant amounts of biomass, which can be used for many purposes. One of the limitations of the use of wetland vegetation is the difficulty to obtain it in a timely manner due to the wetness of the area and the unreliability of weather conditions. In addition, its specific character, associated with a large amount of silica, essential oils and mechanical tissues resulted in abandonment of their mowing, which leads to succession changes in the vegetation growing on them [2]. The significant amount of biomass can be harvested in wetlands subjected to extensive conservation measures. Due to the large amount of biomass obtained this way, the problem of its proper management becomes very important. One of the direct uses of wetland biomass is in agriculture for bedding, for animal feeding as well as a substrate for energy production, including biogas production in agricultural biogas plants.

The wetland plants vary in their feed suitability. The main factor determining the plant's feed value is its high content of protein, sugars, fats, mineral compounds and trace elements [3]. The comparison of the nutritional value of individual plant species or the whole plant communities can be carried out with the system of utility values (Lwu) [4]. This method takes into account the fodder value and the fertility of meadow plants. Its numerical values range from 10 to -3 . Very good fodder plants were valued at 10-9, good 8-7, medium 6-4. Plants with a small use value have the numbers 3-1, while plants that do not represent any fodder value have received the value 0 . All toxic plants were assigned negative numbers from -3 to -1 , depending on the degree of toxicity.

Generally, there are two ways in which plants can be used as a fodder. The first is grazing and the second is summer harvesting and storage as winter fodder for livestock [5], however, plants cannot be cut too late, because they become unpalatable after maturity [6]. The high feed value is mainly observed in early stages of growth and is associated with high sugars and protein content and low dry matter and fiber content [7]. Particularly important is crude protein, which ranges of 10.9-13.8\%DM [8] determine the correct digestion by animals [9]. Nutritive value of fodder obtained from wetland plants can be significantly improved by the ensilage process [2], and in this form, their quality is 
similar to silages of meadow grasses. Therefore, such silages (e.g., common reed silage) can be used as alternative roughage for ruminants and a protein source for breeding cows [10].

The last mentioned direction of using wetland vegetation, i.e. energy production from biogas, seems to be particularly attractive. On the one hand, swamp plants achieve high yields and do not compete for the area that can be used for food production [5], and on the other hand, the biogas production generates large quantities of digestate sludge, which can be used as organic fertilizer [11]. This material contributes to the improvement of both, the chemical and physical properties of soils. Its application reduces the bulk density, improves the hydraulic properties and increases the moisture retention capacity [12]. From the chemical point of view, it is important, that during anaerobic digestion respective forms of nutrients are changed into inorganic forms that are readily available to plants [13].

Due to the possibility of multipurpose application of wetland biomass, the aim of the research was to indicate the most optimal direction of its use. The main focus is on their use as fertilizers and fodder. The results obtained may be a guideline for rational management of wetland biomass resources.

\section{Materials and methods}

The study covered five plant species harvested in mid-summer of 2015 in wetlands in the Narew River Valley, NE Poland: reed sweet-grass (Glyceria maxima; R-S), common reed (Phragmites australis; C-R), tufted sedge (Carex elata; T-S), reed canary grass (Phalaris arundinacea; R-C) and woollyfruit sedge (Carex lasiocarpa; W-S). First, their feed value was determined based on the utility values (Lwu) [4]. The feed value determined for the studied plants was compared with their energy potential and the fertilising value of the fermentation sludge obtained in the laboratory experiment on their bio-methane potential. Before this experiment, the harvested plants were ensiled for 5 months and after this period they were used for research related to their potential in the field of biogas production. The presented article also uses conclusions from the research on carbon dioxide emission from soil fertilized with digestate. This emission was measured by the chamber method during 28 days of incubation of soil samples mixed with digestate. The fertilization value of individual digestates was determined on the basis of changes in selected soil properties before and after incubation. After incubation, the soil was air-dried and analyzed for: $\mathrm{pH}$ (in $0.1 \mathrm{M} \mathrm{KCl} \mathrm{1:2.5} \mathrm{w/v} \mathrm{solution} \mathrm{(measured}$ with HQ40D meter, Hach, USA), soil organic carbon content (SOC) measured with the TOC-L analyzer equipped with SSM-5000A Solid Sample Combustion Unit (Shimadzu, Japan), total nitrogen (N) measured with the VAP50s analyzer (Gerhardt, Germany), total content of phosphorus (P) and potassium $(\mathrm{K})$ determined after sample mineralisation in the microwave oven ETHOS One (Milestone, Italy). The plant-available phosphorus $\left(\mathrm{P}_{2} \mathrm{O}_{5}\right)$ and potassium $\left(\mathrm{K}_{2} \mathrm{O}\right)$ were determined after extraction with calcium lactate solution. Phosphorus was determined spectrophotometrically with the vanadatemolybdate method (UV-1800, Shimadzu, Japan) and sodium and potassium with a flame photometer (BWB Technologies, England). The properties of silages (content of carbon, nitrogen, phosphorus and potassium) have been determined by the same methods. The content of dry matter (DM) was determined with the weight method by oven-drying at $105^{\circ} \mathrm{C}$. Basic statistical analyses of data were calculated using Statistica 13.1 (StatSoft) software. Significant differences amongst soils treated with studied digestates were determined by one-way analysis of variance (ANOVA). The normal distribution of data was checked by the Shapiro Wilk's test and homogeneity of variance was checked with the Levene test.

\section{Results and discussion}

In the utility value system, the highest ranked plant among the studied species is Phalaris arundinaceae (reed canary grass, R-C) with $L w u=7$. Glyceria maximae (reed sweet-grass, R-S) has a value of $L w u=5$, Phragmites australis (common reed, C-R) has $L w u=1$, while Carex elata (tufted sedge, T-S) and Carex lasiocarpa (woolyfruit sedge, W-S) have $L w u=0$.

The silages obtained from the tested wetland plants differ quite clearly in terms of their Sphysical properties and the content of selected elements $(p<0.0001)$. The greatest differences were found in DM. Among the studied plants, silage from $\mathrm{R}-\mathrm{C}$ has the lowest content of total solids. The value obtained by this species is in the range of $350-400 \mathrm{~g} \cdot \mathrm{kg}^{-1}$, which is considered as optimal in silage 
from meadow vegetation [14]. This is beneficial from the feed perspective, because the optimal content of dry matter in silage also corresponds to the increased content of total protein, crude fat, as well as a higher calorific value [15]. The same ensiled material (R-C) also contained the highest amounts of phosphorus, especially compared to W-S and T-S. Relatively much of this element also was found in silage obtained from C-R. Much smaller differences were observed in the potassium content; however, its content in C-R differs significantly from other species, while in R-C and W-S the potassium concentration was quite similar. The only studied parameter that did not differentiate the tested silages was the carbon content. However, as shown in Table 1, the smallest amounts of this element were found in R-C and C-R. Taking into account the determined properties, the highest feed value is obtained from $\mathrm{R}-\mathrm{C}$ silage, providing feed with a sufficiently low content of dry matter and ensuring the highest amounts of nitrogen and phosphorus.

Chemical composition of ensiled plants

Table 1

\begin{tabular}{|c|c|c|c|c|c|}
\hline Plant & DM, \% & $\mathrm{C}, \mathrm{g} \cdot \mathrm{kg}^{-1} \mathrm{DM}$ & $\mathrm{N}, \mathrm{g} \cdot \mathrm{kg}^{-1} \mathrm{DM}$ & $\begin{array}{c}\text { P, } \mathbf{g} \cdot \mathbf{k g}^{-1} \\
\text { DM }\end{array}$ & $\mathrm{K}, \mathrm{g} \cdot \mathrm{kg}^{-1} \mathrm{DM}$ \\
\hline Reed sweet-grass & $58.6 \pm 1.3$ & $425.2 \pm 8.0$ & $25.0 \pm 1.4$ & $21.2 \pm 0.4$ & $13.4 \pm 0.2$ \\
\hline Common reed & $60.1 \pm 1.5$ & $417.0 \pm 6.4$ & $38.3 \pm 1.9$ & $22.2 \pm 1.3$ & $15.1 \pm 0.7$ \\
\hline Tufted sedge & $79.8 \pm 1.1$ & $446.3 \pm 15.7$ & $18.5 \pm 0.6$ & $9.1 \pm 1.2$ & $12.9 \pm 0.3$ \\
\hline Reed canary grass & $38.5 \pm 1.0$ & $414.8 \pm 14.4$ & $38.7 \pm 1.4$ & $23.1 \pm 1.1$ & $11.8 \pm 0.2$ \\
\hline Woollyfruit sedge & $54.4 \pm 0.4$ & $425.9 \pm 18.3$ & $18.0 \pm 0.5$ & $7.1 \pm 1.0$ & $11.8 \pm 0.2$ \\
\hline
\end{tabular}

The feed value of the tested plants looks interesting, when we compare it with the results of the $\mathrm{CO}_{2}-\mathrm{C}$ emissions and degree of mineralization of OM supplied with individual plant digestates. Among the studied wetland plants, the highest emission and therefore the largest amount of potentially mineralized carbon had R-C, while the lowest emission and lowest amount of mineralized carbon in the case of C-R was observed. As a result, C-R turned out to be the plant that used as a substrate for biogas production, enriched the soil with the largest amount of carbon delivered with the material remaining after its anaerobic fermentation. At the same time, C-R is one of the weakest fodder plants while R-C is the best one. Canary reed grass is also distinguished by high content of macroelements which significantly increases its nutritional value [7].

The enrichment of the soil with the digestate obtained from the anaerobic fermentation of wetland plants positively influenced almost all its properties. The most pronounced difference was observed for the potassium content in the soil, because the total and plant-available potassium content almost doubled (Fig. 1). In the case of other elements, differences between soil fertilized with digestate and non-fertilized soil were less clear but statistically significant $(p<0.05)$. The only element, which contents in the untreated soil and soil fertilized with the digestates were very close, was nitrogen.

The fertilizer value varied among the individual digestates. While the nitrogen and carbon content was rather similar, in the case of the other two nutrients, the differences were clear $(p<0.05)$. For plants the most important is the content in soil of these forms of elements that can be easily and quickly assimilated. In this respect, the best digestates are these obtained from T-S and W-S, which can provide plants with the largest amounts of available phosphorus and potassium (Fig. 1), and additionally, can increase soil $\mathrm{pH}$. Taking into account these characteristics, the worst fertilizer appears to be the digestate resulting from $\mathrm{R}-\mathrm{C}$ fermentation, which, as shown by the results of the research on carbon dioxide emission, is also characterized by strong organic matter mineralization enriching the soil with the smallest amounts of organic carbon at the same time.

Previous studies related to the possibility of using the tested wetland plants for biogas production showed that none of these plants can replace maize as a basic substrate in a biogas plant [16]. However, considering their methane production, which is similar to that obtained as a result of swine manure fermentation, they can be treated as interesting co-substrates. When comparing R-C and C-R in the field of biogas production, $\mathrm{R}-\mathrm{C}$ has greater potential in this respect and better energy properties [17], but taking into account the area occupied and the yields obtained, the more interesting plant from the biogas production point of view is, however, C-R. 

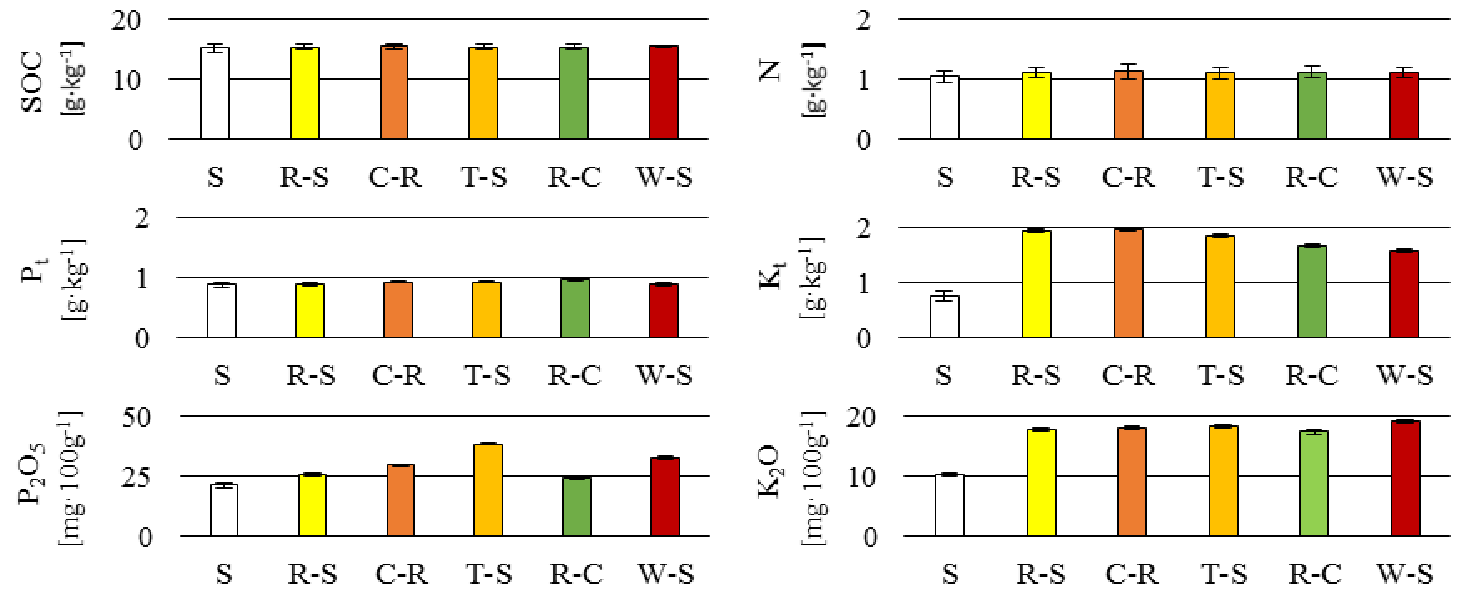

Fig. 1. Selected chemical properties of untreated soil and soil amended with digestates from wetland plants: $\mathrm{S}$ - untreated soil, R-S - reed sweet-grass, C-R - common reed, T-S - tufted sedge, $\mathrm{R}-\mathrm{C}$ - reed canary grass, $\mathrm{W}-\mathrm{S}$ - woollyfruit sedge, $\mathrm{SOC}$ - total organic carbon, $\mathrm{N}$ - total nitrogen content, $\mathrm{P}_{\mathrm{t}}-$ total phosphorus content, $\mathrm{P}_{2} \mathrm{O}_{5}$ - plant available phosphorus content, $\mathrm{K}_{2} \mathrm{O}$ - plant available potassium content

\section{Conclusions}

1. Individual species of wetland plant communities clearly differ in terms of the physical and chemical properties, which may affect the effectiveness of the adopted method of their management.

2. The highest feed value among the tested species has reed canary grass. This plant has the highest utility value $(L w u=7)$ and the lowest content of total solids $\left(385 \mathrm{~g} \cdot \mathrm{kg}^{-1}\right)$, optimal in silage from the feed perspective.

3. Taking into account the fertilizer value of residues after biogas production, the soil enriched with digestate from tufted sedge $\left(38.41 \mathrm{mg} \cdot 100 \mathrm{~g}^{-1}\right.$ of $\left.\mathrm{P}_{2} \mathrm{O}_{5}\right)$ and woollyfruit sedge $\left(19.13 \mathrm{mg} \cdot 100 \mathrm{~g}^{-1}\right.$ of $\mathrm{K}_{2} \mathrm{O}$ ) contains the most for plants available components.

4. Digestate from common reed is important for the protection of soil organic matter resources. As it is slowly mineralized, the soil fertilized with this organic material has the largest amount of organic carbon $\left(15.54 \mathrm{~g} \cdot \mathrm{kg}^{-1}\right)$.

\section{Acknowledgements}

This work was financially supported by the Ministry of Science and Higher Education as a part of the project S/WBiIŚ/01/17.

\section{References}

[1] Millennium Ecosystem Assessment. Ecosystems and Human Well-being: Wetlands and Water Synthesis. World Resources Institute, Washington, DC, USA, 2005. 80 p. [online] [28.02.2018]. Available at: https://www.millenniumassessment.org/documents/document.358.aspx.pdf.

[2] Żurek H., Wróbel B., Zastawny J. Ocena wartości żywieniowej sianokiszonek z łąk bagiennych (Evaluation of nutritive value of silage from bog meadows). Annales UMCS, Sec. E, 61, 2006, pp. 405-411. (In Polish).

[3] Falkowski M., Kukułka I., Kozłowski S. Właściwości chemiczne roślin łąkowych (Chemical properties of meadow plants). University Publisher Poznan University of Life Sciences. Poznan, 1990. 111 p. (In Polish).

[4] Filipek J. Projekt klasyfikacji roślin łąkowych i pastwiskowych na podstawie liczb wartości użytkowej (Scheme of the classification of meadow and pasture plants based on numbers of utility value). Advances in Agricultural Sciences: Postępy Nauk Rolniczych, 4, 1973, pp. 59-68. (In Polish).

[5] Köbbing J.F., Thevs N., Zerbe S. The utilisation of reed (Phragmites australis): a review. Mires and Peat, Volume 13, 2013, pp. 1-14. 
[6] Baran M., Váradyová Z., Kráâmar S., Hedbávn J. The Common Reed (Phragmites australis) as a Source of Roughage in Ruminant Nutrition. Acta Veterinaria Brno, 71, 2002, pp. 445-449.

[7] Grzelak M. Plonowanie szuwaru mozgowego oraz skład chemiczny i wartość energetyczna mozgi trzcinowatej (Yields of reed grass and chemical composition and energetic value of reed canary grass). Fragmenta Agronomica, 26(4), 2009, pp. 38-45. (In Polish).

[8] Nowakowski P., Dobicki A., Mikołajczak Z. Baza pokarmowa bydła mięsnego wypasanego w systemie ekstensywnym Parku Narodowego „Ujście Warty” (The main feed of beef cattle extensively grazing in areas of a National Park "Warta Mouth"). Puławy Diary: Pamiętnik Puławski, Zeszyt 147, 2008, pp. 181-187. (In Polish).

[9] Preś J., Rogalski M. Wartość pokarmowa pasz z użytków zielonych w różnych uwarunkowaniach ekologicznych (Nutritional value of fodders from grassland under different ecological conditions). Problematic Notebooks of Progress of Agricultural Sciences: Zeszyty Problemowe Postępów Nauk Rolniczych, 453, 1997, pp. 39-48. (In Polish).

[10] Asano K., Ishikawa T., Ishida M. Digestibility of common reed (Phragmites communis Trin.) silage as ruminant feed and effects of inclusion levels in the diet of breeding cows on feed intake, ruminal fermentation and blood metabolites. Animal Science Journal, Volume 88, Issue 12, 2017 , pp. 1955-1962.

[11] Hansson P.A., Fredriksson H. Use of summer harvested common reed (Phragmites australis) as nutrient source for organic crop production in Sweden. Agriculture, Ecosystems \& Environment, 102(3), 2004, pp. 365-375.

[12]Nkoa R. Agricultural benefits and environmental risks of soil fertilization with anaerobic digestates: a review. Agronomy for Sustainable Development, 34 (2), 2014, pp. 473-492.

[13] Crolla A., Kinsley C., Pattey E. Land application of digestate. In: Wellinger A., Murphy J. P., Baxter D. (eds) The biogas handbook. Science, production and application. Woodhead Publishing Limited, Cambridge, UK, 2013, pp. 302-325.

[14] Purwin C. Jakość kiszonek z traw i mieszanek traw z roślinami motylkowatymi produkowanych prasami zwijającymi (Quality of silage from grasses and grass mixtures with legumes produced by round balers). University Publisher University of Warmia and Mazury in Olsztyn. Olsztyn, 2007. p. 125. (In Polish).

[15]Radkowski A., Radkowska I., Ocena jakości i wartości pokarmowej kiszonek z runi łąkowej wybranych gospodarstw Polski południowo-wschodniej (Evaluation of the quality and nutritive value of silages from pasture sward in some farms from south-eastern Poland), Zootechnical news: Wiadomości Zootechniczne, R. LII, 1, 2014, pp. 32-37. (In Polish).

[16]Roj-Rojewski S., Wysocka-Czubaszek A., Czubaszek R., Banaszuk P. Does wetland biomass provide an alternative to maize in biogas generation? In: Mudryk K., Werle S. (eds.) Renewable Energy Sources: Engineering, Technology, Innovation. Springer Proceedings in Energy, Springer International Publishing, 2018, pp. 127-137.

[17] Alberski J., Olszewska M., Bałuch-Małecka A., Kurzeja M. Wartość energetyczna biomasy z użytkowanych ekstensywnie ląk warkalsko-trojańskich (Energy value of biomass from the extensively used Warkały-Trojan meadows). Grassland Science in Poland: Łąkarstwo w Polsce, 18, 2015, pp. 7-16. (In Polish). 